Acta Biologica Plantarum Agriensis 5(1): 48 (2017) ISSN 2061-6716 (Print), 2063-6725 (Online) http://abpa.ektf.hu/
DOI:10.21406/abpa.2017.5.1.48

$4^{\text {th }}$ CC 2017 Abstract

Poster

\title{
The BRYOFLORA OF THE PINKA GORGE
}

A Pinka-szurdok mohaflórája

\section{Kornél BARÁTH ${ }^{1}$ \& Peter ERZBERGER ${ }^{2}$}

1Department of Biology, Savaria Campus, Eötvös Loránd University, H-9700 Szombathely, Károlyi Gáspár tér 4., Hungary; ${ }^{2} \mathrm{D}-10823$ Berlin, Belziger Str. 37, Germany; e-mail: barath.kornel@sek.elte.hu

The River Pinka originates in eastern Austria and reaches the territory of Hungary at first near Felsőcsatár. The river cuts through the Nagyvilágos Hill forming a gorge. This unique landscape is home to special flora and fauna. The authors have been studying the bryophyte diversity and distribution patterns in the Pinka Gorge in April, July, and August of 2016 and in March, April and July of 2017. The examined area was ca. $2500 \mathrm{~m}$ long and maximum $60 \mathrm{~m}$ wide along the right side of the river. During the field study, altogether 140 bryophyte species - 115 Bryophyta and 25 Marchantiophyta species - were found in this highly valuable Natura 2000 territory. The main reason for the quite high bryophyte diversity may be the several different habitat types that can be found in this area. Authors succeeded in finding occurrences of several vulnerable and endangered species, such as Isothecium myosuroides Brid. (EN), Porella arboris-vitae (With.) Grolle (EN), Amphidium mougeotii (Bruch \& Schimp.) Schimp. (VU), Bryum pallens Sw. ex anon. (VU), Leiocolea collaris (Nees) Schljakov (VU), Nowellia curvifolia (Dicks.) Mitt. (VU), Eurhynchium flotowianum (Sendtn.) Kartt. (VU), Orthotrichum patens Bruch ex Brid. (VU), Ulota bruchii Hornsch. ex Brid. (VU). The results emphasize the importance of further research in this area. 